\title{
Performances of Heterobranchus longifilis Fed Full-Fatted Maggot Meal Supplemented Diets in Mini-Flow through System
}

\author{
Sogbesan, Olukayode Amos \\ Department of Fisheries, Modibbo Adama University of Technology, Yola, Nigeria
}

\begin{abstract}
The growth response, nutrient utilization, cost benefits and haematological responses of three hundred (300) Heterobranchus longifilis fingerlings stocked at twenty per 50L plastic bowls in triplicate were fed full-fatted maggot meal supplemented diets for 70 days in mini-flow through system. Five diets name $M_{1}-0 \%$ maggot meal, $M M_{2}-25 \%$ maggot meal, $M M_{3}-50 \%$ maggot meal, $M M_{4^{-}}-75 \%$ maggot meal and $M M_{5^{-}} 100 \%$ maggot meal that were isonitrogenous at $40.0 \% \mathrm{CP}$ and caloric content range of $2017.9-2092.3 \mathrm{~kJ} / 100 \mathrm{~g}$ were fed to the fish. The result of the experiment showed that the higher the proportion of maggot in the meal, the higher the ether extract and crude fibre. No significant difference $p>0.05$ existed between ash content of the experimental diets. Diet $M M_{2}$ had the best growth performance and highest metabolic growth rate with a significant difference $p<0.05$ with other diets fed fish. No significant differences $p>0.05$ existed between the growth indices in diets $M M_{1}, M M_{3}$, and $M M_{4}$. A positive correlation $(r=1.0)$ existed $(p<0.05,0.25)$ between the growth parameters for the different experimental diets. Highest correlation $r^{2}=0.9981$ existed $p<0.05$ between metabolic growth rate within the treatments. Highest Haematocrit (23\%), Haemoglobin content (7.68g/dl) and whole blood clotting time (46 sec) were recorded from $\mathrm{H}$. longifilis fed $M M_{5}$. Without any reservation, inclusion of full-fatted maggot meal diet is recommended as feed in the diet of $\mathrm{H}$. longifilis to substitute $75 \%$ fishmeal for growth, higher profitability and better healthy conditions of the fish in other to ensure sustainable aquaculture in Nigeria.
\end{abstract}

Key words: Full-fatted maggot meal; fishmeal; growth; haematology; economic indices.

\section{Introduction}

Fish production through aquaculture is globally constrained by its dependence on a finite resource of animal protein origin (pelagic fish), which stocks are declining due to high competition from other allied dependence. The Maggot; which is the larva form of Housefly (Musca domestica) is not been conventional animal protein source of man and this could serve as a relative alternative of fishmeal (Madu et al., 2003). This organism grows extensively on livestock and human dung, household and food waste, perishable agricultural products, orchard wastes and so on; where it digests them to odour free "scum" with high nutrient value. Maggot is readily available and has been accredited for its high quality protein with amino acids profile showing its biological value to be superior to soybean and groundnut cake (Adejinmi, 2000, Eyo, 2003 and Sogbesan, 2006).

The extensive utilization of fish meal (a more reliable animal protein source) by man, livestock and poultry industries has resulted into geometrical increase in the price of fishmeal; which is called for investigation into other cheap alternative sources of fish meal. feed ingredients that will provide the required nutrient for the fish at cheaper cost if production from aquaculture sector and bridge the gap between fish demand and supply in Nigeria (Madu et al., 2003).

Heterobranchus longifilis is one of the major catfish species of the Family Clariidae. This fish inhabits freshwater bodies (Reed et al., 1967 and Idodo-Umeh, 2003). Fagbenro (1989) reported that Heterobranchus is tolerant to low dissolve oxygen and other adverse aquatic conditions including high turbidity. H. longifilis feeds on any available food, including plankton, insects, fish, detritus, benthic invertebrates (annelids) and tadpoles (Olufeagba, 1999). The optimum protein requirement for the fingerling stage as reported by Fagbenro et al. (1992) is $42.5 \%$ crude protein. H. longifilis is a highly priced fish in Nigeria along with other African catfish species due to their good taste and flavour. The Nigerian fish farmers have not been able to meet the demand for the species by the populace. Hence, there is a need to boost the production of this highly commercially demanded culturable fish with high growth rate for food sustainability in Nigeria. Blood is a major index of physiological, pathological and nutritional status of an organism. Any change in the constituent component of blood sample when compared to the normal values could be used to interpret the metabolic state of the animal and the influence of treatment given to the animal (Babatunde et al., 1992). Baron (1980) observed that haematological changes could be attributed to environmental conditions such as oxygen and food composition (like proteins, vitamins and mineral salts).

The study was embarked upon as a result of information through an extension services survey from farmers that fed their fish with maggot and the fear nursed since the evolvement of the technology. The result 
from this study will serve as an additional information to resolve the problem of high price of animal protein source in fish feed and assure the safety use of full-fatted maggot meal in the diet of H. longifilis.

\section{Experimental system}

\section{Materials And Methods}

The experiment was carried out indoor in the Fish Nutrition Laboratory of Aquaculture and Biotechnology Department of the National Institute for Freshwater Fisheries Research (NIFFR), New-Bussa, Nigeria.

Five experiment sets in triplicates were used for this experiment. A total of fifteen (15) indoor miniflow through system, $0.25 \mathrm{~m}$ depth and $0.55 \mathrm{~m}$ diameter circular plastic tanks of 50 liters capacity each were used for the trials. Water was supplied to each tank from 30,000litres head tanks. Each unit had a control for comparison. The plastic tanks were cleaned, disinfected and allowed to dry for 24 hours, after which water was supplied to two-third of the size of the tank and were covered with a net of mesh size $3 \mathrm{~mm}$ to protect the fish from jumping out of the tanks. A constant photoperiod of 12 hours light and 12 hours dark was maintained

\section{Experimental Fish}

A total number of 250 fingerlings of Heterobranchus longifilis of weight range $1.69 \mathrm{~g}-2.45 \mathrm{~g}$ (mean $=$ $1.98 \pm 0.083 \mathrm{~g}$ ) and total length range of $6.2 \mathrm{~cm}-7.2 \mathrm{~cm}$ (mean $=6.5 \pm 0.08 \mathrm{~cm}$ ) were purchased from the Hatchery Unit of NIFFR. They were acclimatized for one week in plastic holding tanks of $2.0 \mathrm{~m} \times 0.5 \mathrm{~m} \times 0.4 \mathrm{~m}$ in the Fish Nutrition Laboratory of NIFFR, aerated with Erckman Electric Aerator and fed a compounded NIFFR-feed of $35 \%$ crude protein, New- Bussa.

The fingerlings were randomly sorted, weighed, stocked into the indoor experimental tanks at the rate of fifteen fingerlings per tank and starved overnight before the commencement of the feeding trial. The fish were monitored for mortality daily. Dead fish were removed, counted and recorded for determination of survival rate.

\section{Experimental diets}

Five experimental diets were formulated and prepared for this experiment as shown in Table 1. Diet $\mathrm{MM}_{1}$, which contains $0 \%$ maggots meal was used as the control. Diets $\mathrm{MM}_{2}, \mathrm{MM}_{3} \mathrm{MM}_{4}$ and $\mathrm{MM}_{5}$ - containing $25 \%, 50 \%, 75 \%$ and $100 \%$ supplemented maggot meal respectively. All diets were isonitrogenous at $40 \%$ and isocaloric at $4824.4-5002.5 \mathrm{kcal} / \mathrm{kg}$.

\section{Production of Maggot meal}

Maggots used for this experiment were cultured according to (Nuov et al, 1995 and Madu and Ufodike, 2003) methods. The collection was done as described by (Adejinmi, 2000 and Sogbesan et al., 2006) using screen nets. The maggots are photonegative, so in an attempt to escape from the traces of sunlight, they pass through the $3 \mathrm{~mm}$-mesh size net and were collected into a basin under the net. machine.

Maggots collected were weighed, dried under the sun and grounded into powdery form using blender

\section{Sampling and monitoring of the experimental fish}

The length and weight of each fingerling in each tank was measured at the commencement of the experiment. Subsequently, 5 fingerlings were taken randomly from each tank once a week and weighed with beam balance to access the growth rate. The sampling exercises were carried out in the morning before feeding the fish. Any dead fish is quickly removed and recorded to determine the survival rate. The experiment lasted for 10 weeks.

\section{Water Quality.}

The water quality parameters were monitored by the staffs of Limnology Division of NIFFR, NewBussa, Nigeria and average value for temperature; dissolved oxygen, hydrogen ion concentration $(\mathrm{pH})$ and conductivity were $29.5^{\circ} \mathrm{C}, 5.8 \mathrm{mg} / \mathrm{l}, 7.2$ units and $220 \mu$ mhos $\mathrm{cm}^{-3}$ respectively.

\section{Biochemical and haematological analyses}

Proximate composition was carried out using the Association of Official Analytical Chemists methods (AOAC 2000). The haematocrit was determined by the microhaemotocrit method, haemoglobin was determined using the cynomethaemoglobin method and the coulter haemoglobinometer (Coulter, U.K.). Whole blood clotting time by as the time (sec) that it took blood introduced into a syringe to start to clot. 


\section{Fish Performance indices and statistical analysis}

For this study, growth was expressed as weight gain, relative weight gain, specific growth rate, metabolic growth rate, condition factors (Bagenal, 1978) and survival rate (Fasakin et al., 2001). Feed utilization indices were expressed as Feed conversion ratio, Protein efficiency ratio (Wilson, 1989) and protein rating (Steffens, 1981), as follows:

Mean weight gain $=\mathrm{W}_{\mathrm{f}}-\mathrm{W}_{\mathrm{i}} / \mathrm{n}$.

Relative Growth Rate $=($ Weight gain $/$ Initial body weight $) \times 100$.

Specific Growth Rate $=\left(\log w-\log w_{I} / t\right) \times 100$.

Metabolic growth rate $(\mathrm{MGR})=$ Live body weight gain $/\left\{\left(\mathrm{W}_{\underline{\mathrm{i}}}+\mathrm{W}_{\mathrm{f}}\right)\right\}^{0.8}$

Voluntary feed intake $($ VFI\% $)=\underline{100 \times \text { FI }}$

Experimental period (days)

$$
\left(\mathrm{W}_{\mathrm{i}}+\mathrm{W}_{\mathrm{f}}\right) \times \mathrm{t}
$$

Food Conversion Ratio= Feed intake (g) / Weight gain (g).

Protein efficiency rate $=$ Weight gain $/$ Protein intake

Protein rating $=$ Daily protein intake $\mathrm{x}$ PER.

Cost benefits in terms of Profit Index (PI), incidence of cost (IC), and benefit cost ratio of substituting fish meal with maggot meal in the culture of Heterobranchus longifilis were determined according to New (1989), Faturoti and Lawal (1992) and Mazid et al. (1997).

Profit Index=Value of fish $(\#) /$ cost of feed $(\#)$

Incidence of Cost=Cost of feed $(\$) /$ mean weight gain of fish produced $(\mathrm{g})$

Benefit: cost ratio $(\mathrm{BCR})=\underline{\text { Total cost of fish cropped }(\mathbb{N})}$

$$
\text { Total expenditure ( } \$ \text { ) }
$$

All data collected were subjected to analysis of variance (ANOVA). Comparisons among treatment means were carried out by one way analysis of variance followed by Tukey's test (0.05). Least Significance differences (LSD) was used to determine the level of significance among treatments. Correlation and regression analysis was carried out to determine the relationship between the treatments and some of the parameters using SPSS 16.0 and Graph pad Instat packages Windows 2007.

\section{Results}

Average value for temperature; dissolved oxygen, hydrogen ion concentration $(\mathrm{pH})$ and conductivity were $29.5^{\circ} \mathrm{C}, 5.8 \mathrm{mg} / \mathrm{l}, 7.2$ units and $220 \mu$ mhos $\mathrm{cm}^{-3}$ respectively.

The crude protein content of the five experimental diets were $41.16 \%, 41.43 \%, 41.71 \%, 41.98 \%$ and $42.25 \%$ for $0 \%, 25 \%, 50 \%, 75 \%$ and $100 \%$ maggot meal-based diet respectively (Table2). The highest crude lipid, $17.04 \%$ was in $100 \%$ maggot meal based diet while lowest crude lipid, $8.87 \%$ was in the control diet. The gross energy values, which are $1742.13 \mathrm{~kJ} / 100 \mathrm{~g}, 1794.55 \mathrm{~kJ} / 100 \mathrm{~g}, 1854.81 \mathrm{~kJ} / 100 \mathrm{~g}, 1898.91 \mathrm{~kJ} / 100 \mathrm{~g}$ and $1951.04 \mathrm{~kJ} / 100 \mathrm{~g}$ increased as the maggot meal inclusion increased from the control diet to $100 \%$ maggot meal inclusion diet respectively. A gradual rise in the line graph of $\mathrm{MM}_{1}$ from week 1 till week6 when there was a slight decrease and rise again in week 7 till the end of the experimental period. A gradually increase and rise in the slope of graph line $\mathrm{MM}_{2}$ was recorded and shown in Figure 1. The growth pattern recorded in $\mathrm{MM}_{5}$ did not rise sharply as seen in other diets. Highest mean weight gain of $8.73 \mathrm{~g} /$ fish was recorded in $\mathrm{MM}_{2}$ while the lowest of $4.80 \mathrm{~g} /$ fish was recorded in $\mathrm{MM}_{5}$. The highest SGR $1.01 \%$ was recorded in $\mathrm{MM}_{2}$ while the lowest SGR, $0.72 \%$ was recorded in $\mathrm{MM}_{5}$. All growth indices were insignificantly different $(\mathrm{p}=0.3614$ and $\mathrm{F}=1.198)$. The FCR ranged within 1.63-2.01. Highest PER of 1.48 was recorded from $\mathrm{MM}_{2}$ while the lowest, 1.17 from $\mathrm{MM}_{5}$ (see Table 3). The highest gross energy intake of $2560.82 \mathrm{~kJ} / 100 \mathrm{~g}$ was recorded in $\mathrm{MM}_{2}$ while the lowest of $1892.51 \mathrm{~kJ} / 100 \mathrm{~g}$ was recorded in $\mathrm{MM}_{5}$. Within the growth indices, highest significant correlation $\mathrm{r}=0.9997$ $(\mathrm{p}<0.05)$ was recorded between specific growth rate and metabolic growth rate while the lowest $\mathrm{r}=0.9914$ $(\mathrm{p}<0.05)$ was recorded between weight gain and specific growth rate. The feed utilization indices showed highest negative correlation $r=-0.9956$ between PER and FCR while the lowest of $r=0.0189, p>0.05$ existed between FCR and VFI. There was no significant difference between the feed utilization indices with $p=0.9699$. The haematocrit and haemoglobin content were higher in maggot inclusion diet compared to the control. The best $\mathrm{BCR}$ of 1.55 was recorded from $\mathrm{MM}_{2}$. Table 4 presented information on correlation matrices ( $\mathrm{r}$ ) of the different inclusions of maggot meal utilization by the fish fed that very strong and significant correlation existed between each of the diet utilization. Table 5 detailed strength of the association within the parameters used in adjudging the maggot meal utilization

\section{Discussion}

The use of maggot meal in $\mathrm{H}$. longifilis diets appear to be advantageous especially as a reliable substitute for fish meal (clupeids) which harvest from the wild is been frown at by the federal government of 
Nigeria due to over exploitation by artisanal fishermen. The absence of negative effect on fish growth and physiology indicated that inclusion of maggot meal will not hampered both the development and health being of fish feed. Similar report had been made by Akpodiete and Okagbare (2000) when chicken were fed maggot meal. The study showed no significant difference in general haematological and serum of the chicken fed even in comparison to the control which indicated good quality of maggot meal as a good substitute for fish meal. Reduction in WBC showed a reduction in pathogenic load and need to shoot-up immunity to combat such pathogens as a result of maggot meal. This observation was in line with that of Adejinmi (2000).

The control diet would have been expected to show the best growth performance especially in terms of weight gain since it contains fish which is a high level of protein that has been known as the best feed ingredient for fish (Lovell, 1994 and Massomotu et al.,1996), but this was not so. However, Lovell (1994) reported that the biological value of protein source does not only depend on its amino acid profile but also on its digestibility as indicated by digestibility energy which increased with increase maggot meal inclusion. Fibre content of feed has been documented to enhance growth performance in fish (Steffen, 1989), the low fibre content of control diet might has also been a considerable factor for a low growth performance especially in relative to $25 \%$ maggot meal-based diet. The results on the survival rate indicated that the feeding of $\mathrm{H}$. longifilis fingerlings with maggot diets can result into high survival rate. This cannot be unconnected to the high acceptability of this meal as indicated by the voluntary feed indicate and better protein rating of the feeds which was observed during the study (Faturoti, 1991, Babatunde, 1997, Newton et al.,2005).

The actual feed production cost and harvesting of maggot (Sogbesan et al., 2006) is confounded by the associated benefit to livestock- poultry producers' gain from manure management. Since fish meal production requires labour, fuel and equipment on could assume that the equipment used to collect poultry manure, culture and harvest live maggot and process dry maggot meal might cost the same amount as reported by Newton et al. (2005) but the cost of feed production did not agree with their report. The cost benefit report in this study also justifies the growth performance findings. Based on these results, the use of maggot to substitute the costly fishmeal to about $75 \%$ inclusion levels is recommended to fish farmers and feed industry though there is a need to appraise large scale production of maggot.

\section{Acknowledgement:}

The author acknowledge the Annual research grant provided for staff development by the Federal Government of Nigeria through National Institute of Fresh Water Fisheries Research, New-Bussa, Nigeria, Prof. Ladu BMB the Ex. Executive Director and Dr. C.T. Madu, the Ex. Head of aquaculture and Biotechnology Division for the support accorded to this research and proof reading of the manuscript

\section{References}

[1]. Adejinmi, O.O. (2000). The chemical composition and nutritional potential of soldier fly larvae (Hermetia elucens) in poultry rations. University of Ibadan., PhD. Thesis. Pp292.

[2]. Akpodiete, O.J. and Okagbare, G.O. (2000). Biochemical effects of feeding maggot meal to meat-type and egg-type chickens. In. Book of proceedings 25th Annual NSAP Conference (Ukachukwu, S.N., Ibeanuchi, J.A., Ibe, S.N., Ezekwe, A.G. and Abasiekong, S.F. eds.) Pp123-124.

[3]. AOAC (2000). Official Methods of Analysis of the Association of official analytical chemist. Vol.13., AOAC Washington, USA, $1234 \mathrm{pp}$

[4]. Babatunde, A.A. (1990). Growth and survival of hatchery produced hybrid of Heterobranchus bidorsalis x Clarias garepinus fry fed on varying protein diets and harvested plankton.

[5]. M.Sc. Thesis, University of Ibadan, Ibadan.

[6]. Babatunde, G.M., Fajimi, O.A., Oyejide, O.A. (1992). Rubber seed oil versus palm oil in the broiler chicken diet. Effect on performance nutrient, digestibility, haematology and carcass characteristics. Animal feed Science technology. 35: 133-146.

[7]. Bagenal, T.B. (1978). Methods of assessment of fish production on freshwater. Blackwell Scientific Publication Oxford. IBP Handbook No.3 pp101-126.

[8]. Baron, D.N. (1980). A short textbook of chemical Pathology. $3^{\text {rd }}$ Edition, E.L.S.B. Guilford, Surrey, 246pp.

[9]. Eyo, A.A.(2003).Fundamentals of fish Nutrition and diet development - An overview. In: Proceeding of the Joint Fisheries Society of Nigeria/National Institute For Freshwater Fisheries Research/FAO-National Special Programme For Food Security National workshop on Fish feed development and Feeding Practices in Aquaculture (Eyo, A. A. Ed) held at National Institute for Freshwater Fisheries Research, New- Bussa. 15th -19th September, 2003 Pp1-33.

[10]. Fagbenro, O. A.(1989).Observation on the dietary habits of the Clariid Catfish, Heterobranchus bidorsalis in Owena reservoir. In Proceedings of the $4^{\text {th }}$ Annual Conference of Aquatic Sciences (Ed. Faturoti, E. O., et al.,) pp 17-24.

[11]. Fagbenro, O.A., Balogun, A.M.and Anyanwu, C.N.(1992). Optimum dietary protein level for Heterobranchus bidorsalis fingerlings fed compounded diets. Nigerian. Journal of Applied Fisheries and Hydrobiology 1:41-45.

[12]. Fasakin, E.A. and Balogun, A.M., Fagbenro, O.A.(2001).Evaluation of sun-dried water fern, Azolla africana, and duckweed, Spirodela polyrrihza in practical diets for Nile Tilapia Oreochromis niloticus (L) fingerlings. Journal of Applied Aquaculture11:8392.

[13]. Faturoti, E. O. (1991). Fish Nutrition and Feeding. Unpublished lecture manual. University of Ibadan, Ibadan.

[14]. Faturoti, E. O. and Lawal, L.A. (1986). Performance of supplementary feeding and organic manuaring on the production of Oreochromis niloticus. Journal of West Africa Fisheries 1:25-32.

[15]. Idodo-Umeh, G. (2003). Freshwater Fisheries of Nigeria. Taxonomy, Ecological, Notes, Diets and Utilization. Published by IdodoUmeh Publishers Limited, Benin-city, Nigeria. 232p. 
[16]. Lovell, R.T. (1994). Compensatory gain in fish. Aquacultural Management. 20(1): 91 - 93.

[17]. Massumotu, T., Ruchmat, T. and Ito, Y. (1996). Amino acid availability values for Several protein sources for yellow tail (Seriola quinqueradiate). Aquaculture 146 (1996)109-119.

[18]. Madu, C.T. nad Ufodike, B.C. (2003). Growth and Survival of Catfish (Clarias anguillaris) juveniles fed tilapia and maggot as unconventional diets. Journal of Aquatic Sciences 18(1):47-51.

[19]. Massumotu, T., Ruchmat, T. and Ito, Y. (1996). Amino acid availability values for several protein sources for yellow tail (Seriola quinqueradiate). Aquaculture, 146:109-119.

[20]. Mazid, M.A.; Zaher M.; Begum, N.N.; Aliu, M.Z and Nahar, F. (1997). Formulation of cost-effective feeds from locally available ingredients for carp polyculture system for increase production. Aquaculture 151: 71-78.

[21]. Nouv, S., Little,S. and Yakupitiyage, A.(1995). Nutrient flows in integrated pig, maggot and fish production system. Aquaculture Research 26:601-604.

[22]. New, M.B. (1989). Formulated aquaculture feeds in Asia: Some thoughts on comparative economics, industrial potential, problems and research needs in relation to small-scale farmer. In. Report of the workshop on shrimps and fin fish feed development (Bahru, J Ed.). ASEAN/SF/89/GEN/11.

[23]. Newton, L., Sheppard, C., Watson, W.D., Burtle, G and Dove, R. (2005). Using the black Soldier fly, Hermetia illucens, as a valueadded tool for the management of some manure. A report for Mike Williams. State of Science, Animal manure waste management, San Antono TX 17p.

[24]. Olufeagba, S.O. (1999). Induced Triploid of Heterobranchus longfilis Valencienuess (1840) and its aquacultural potentials. Ph.D. Thesis. University of Ilorin, Ilorin. 166p.

[25]. Reed, W., Burchard, J., Hopson, A.J., Jenness, J and Yaro, I.(1967). Fish and Fisheries of Northern Nigeria. Published by Ministry of Agriculture Northern Nigeria, Zaria, Nigeria. pp78-79.

[26]. Steffens, W. (1989). Principles of fish nutrition. Ellis Horwood Lmited, U.K. Pp384

[27]. Sogbesan, A.O., Ajuonu, D.N., Musa, B.O. and Adewole, A.M. (2006) Harvesting techniques and evaluation of maggot meal as dietary animal protein source for "Heteroclarias" fingerlings outdoor concrete tanks. World Journal of Agricultural Sciences2 (3).

[28]. Wilson, R.P (1989). Amino acids and proteins. In: Fish Nutrition (J.E Halver, Ed). Academic Press Inc., California. Pp111 - 115.

Table 1. Formulation and Production cost of experimental diets.

\begin{tabular}{|c|c|c|c|c|c|}
\hline Feed Ingredients & $\begin{array}{l}\text { 0\% Maggot meal } \\
\text { (Control) }\end{array}$ & $\begin{array}{ll}25 \% & \text { Maggot } \\
\text { meal } & \\
\end{array}$ & $\begin{array}{l}\mathbf{5 0 \%} \text { Maggot } \\
\text { meal }\end{array}$ & $\begin{array}{l}75 \% \text { Maggot } \\
\text { meal }\end{array}$ & $\begin{array}{l}100 \% \\
\text { Maggot meal }\end{array}$ \\
\hline Fish Meal & 30.0 & 22.5 & 15.0 & 7.5 & - \\
\hline Full fatted Maggot Meal & - & 7.5 & 15.0 & 22.5 & 30.0 \\
\hline Blood Meal & 5.0 & 5.0 & 5.0 & 5.0 & 7.5 \\
\hline Groundnut Cake & 30.0 & 33.0 & 42.0 & 49.5 & 51.5 \\
\hline Yellow Maize & 30.0 & 28.0 & 18.0 & 10.5 & 6.0 \\
\hline Soybean Oil & 2.0 & 2.0 & 2.0 & 2.0 & 2.0 \\
\hline Binder & 0.5 & 0.5 & 0.5 & 0.5 & 0.5 \\
\hline Bone meal & 0.5 & 0.5 & 0.5 & 0.5 & 0.5 \\
\hline Salt & 0.5 & 0.5 & 0.5 & 0.5 & 0.5 \\
\hline Vitamin / Mineral Premix & 1.5 & 1.5 & 1.5 & 1.5 & 1.5 \\
\hline Total & 100.0 & 100.0 & 100.0 & 100.0 & 100.0 \\
\hline Calculated Crude Protein \% & 40.10 & 40.01 & 40.01 & 40.01 & 40.00 \\
\hline Calculated Gross Energy kJ/100g & 2018.05 & 2026.29 & 2039.17 & 2047.62 & 2049.46 \\
\hline Cost of production ( $\$ / \mathrm{kg}$ of feed) & 82.29 & 71.64 & 64.69 & 57.74 & 50.79 \\
\hline Cost of Production $\$ / \mathrm{kg}$ of feed & 0.51 & 0.44 & 0.40 & 0.36 & 0.31 \\
\hline
\end{tabular}

Exchange rate of N161.33 (NGN) to 1\$ (US dollar)

Table 2 Proximate and energy composition of the experimental diets treatments.

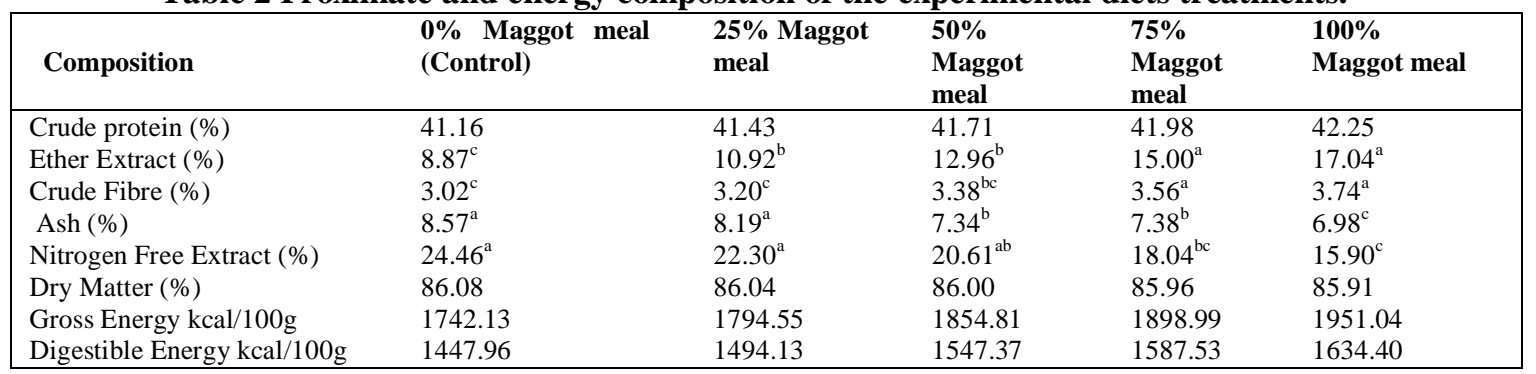

All data with different superscripts are significantly different at $(\mathrm{p}<0.05)$

Table 3. Growth, Feed utilization, haematological indices and Cost benefits of Heterobranchus longifilis fingerlings fed maggot meal supplemented diets.

\begin{tabular}{|llllll|}
\hline PARAMETER & $\begin{array}{l}\text { 0\% } \\
\text { meal (Control) }\end{array}$ & $\begin{array}{l}\text { Maggot } \\
\text { meal }\end{array}$ & $\begin{array}{l}\mathbf{5 0 \%} \text { Maggot } \\
\text { meal }\end{array}$ & $\begin{array}{l}\text { 75\% Maggot } \\
\text { meal }\end{array}$ & $\begin{array}{l}\text { 100\% } \\
\text { meal }\end{array}$ \\
\hline Initial weight (g) & 2.10 & 2.15 & 2.10 & 2.08 & 2.18 \\
Final Weight (g) & 9.30 & 10.88 & 9.49 & 7.43 & 6.98 \\
Weight gain (g/fish) & $7.20^{\mathrm{a}}$ & $8.73^{\mathrm{a}}$ & $7.39^{\mathrm{a}}$ & $5.35^{\mathrm{b}}$ & $4.80^{\mathrm{b}}$ \\
Relative growth rate (\%/fish) & $343^{\mathrm{a}}$ & $406^{\mathrm{a}}$ & $352^{\mathrm{a}}$ & $257^{\mathrm{b}}$ & $220^{\mathrm{b}}$ \\
Metabolic growth rate & $29.36^{\mathrm{a}}$ & $31.99^{\mathrm{a}}$ & $29.74^{\mathrm{a}}$ & $25.22^{\mathrm{b}}$ & $23.32^{\mathrm{b}}$ \\
Specific growth rate (\%/day) & $0.92^{\mathrm{a}}$ & $1.01^{\mathrm{a}}$ & $0.94^{\mathrm{a}}$ & $0.79^{\mathrm{b}}$ & $0.72^{\mathrm{b}}$ \\
Voluntary feed intake & $1.71^{\mathrm{a}}$ & $1.56^{\mathrm{b}}$ & $1.55^{\mathrm{b}}$ & $2.56^{\mathrm{b}}$ & $1.51^{\mathrm{b}}$ \\
\hline
\end{tabular}




\begin{tabular}{|c|c|c|c|c|c|}
\hline Feed conversion ratio & $1.89^{\mathrm{ab}}$ & $1.63^{\mathrm{a}}$ & $1.70^{\mathrm{a}}$ & $1.94^{\mathrm{b}}$ & $2.01^{b}$ \\
\hline Protein rating & $0.10^{\mathrm{a}}$ & $0.12^{\mathrm{a}}$ & $0.11^{\mathrm{a}}$ & $0.08^{\mathrm{b}}$ & $0.07^{\mathrm{a}}$ \\
\hline Protein efficiency rate & $1.28^{\mathrm{b}}$ & $1.48^{\mathrm{a}}$ & $1.40^{\mathrm{a}}$ & $1.22^{\mathrm{b}}$ & $1.17^{\mathrm{b}}$ \\
\hline Gross Energy Intake $(\mathrm{kJ} / 100 \mathrm{~g})$ & $2383.23^{\mathrm{a}}$ & $2560.82^{\mathrm{a}}$ & $2337.06^{\mathrm{a}}$ & $1974.95^{\mathrm{b}}$ & $1892.51^{\mathrm{b}}$ \\
\hline Survival $(\%)$ & 100.0 & 99.0 & 99.5 & 98.5 & 99.5 \\
\hline Condition factor & $1.37^{\mathrm{ab}}$ & $1.23^{\mathrm{b}}$ & $1.6^{\mathrm{a}}$ & $0.97^{\mathrm{c}}$ & $0.95^{\mathrm{c}}$ \\
\hline Haematocrit (\%) & $17^{\mathrm{a}}$ & $22^{\mathrm{a}}$ & $22^{\mathrm{a}}$ & $20^{\mathrm{a}}$ & $23^{\mathrm{ab}}$ \\
\hline Haemoglobin $(\mathrm{g} / \mathrm{dl})$ & $5.67^{\mathrm{a}}$ & $7.21^{b}$ & $7.33^{\mathrm{b}}$ & $6.68^{b}$ & $7.68^{\mathrm{bc}}$ \\
\hline White blood cell & 1.80 & 1.69 & 1.65 & 1.59 & 1.63 \\
\hline Clotting time $\left(\mathrm{sec}^{-1}\right)$ & $45^{\mathrm{a}}$ & $40^{\mathrm{b}}$ & $42^{\mathrm{b}}$ & $46^{\mathrm{a}}$ & $45^{\mathrm{a}}$ \\
\hline Profit index & $7.86^{\mathrm{b}}$ & $9.90^{\mathrm{b}}$ & $11.14^{\mathrm{ab}}$ & $11.83^{\mathrm{a}}$ & $12.99^{\mathrm{a}}$ \\
\hline Incidence of Cost & $1.56^{\mathrm{b}}$ & $1.17^{\mathrm{a}}$ & $1.10^{\mathrm{a}}$ & $1.13^{\mathrm{a}}$ & $1.03^{\mathrm{a}}$ \\
\hline Benefit cost ratio (BCR) & $1.34^{\mathrm{b}}$ & $1.55^{\mathrm{c}}$ & $1.44^{\mathrm{bc}}$ & $1.17^{\mathrm{a}}$ & $1.07^{\mathrm{a}}$ \\
\hline
\end{tabular}

- All data with different superscripts are significantly different at $(\mathrm{p}<0.05)$

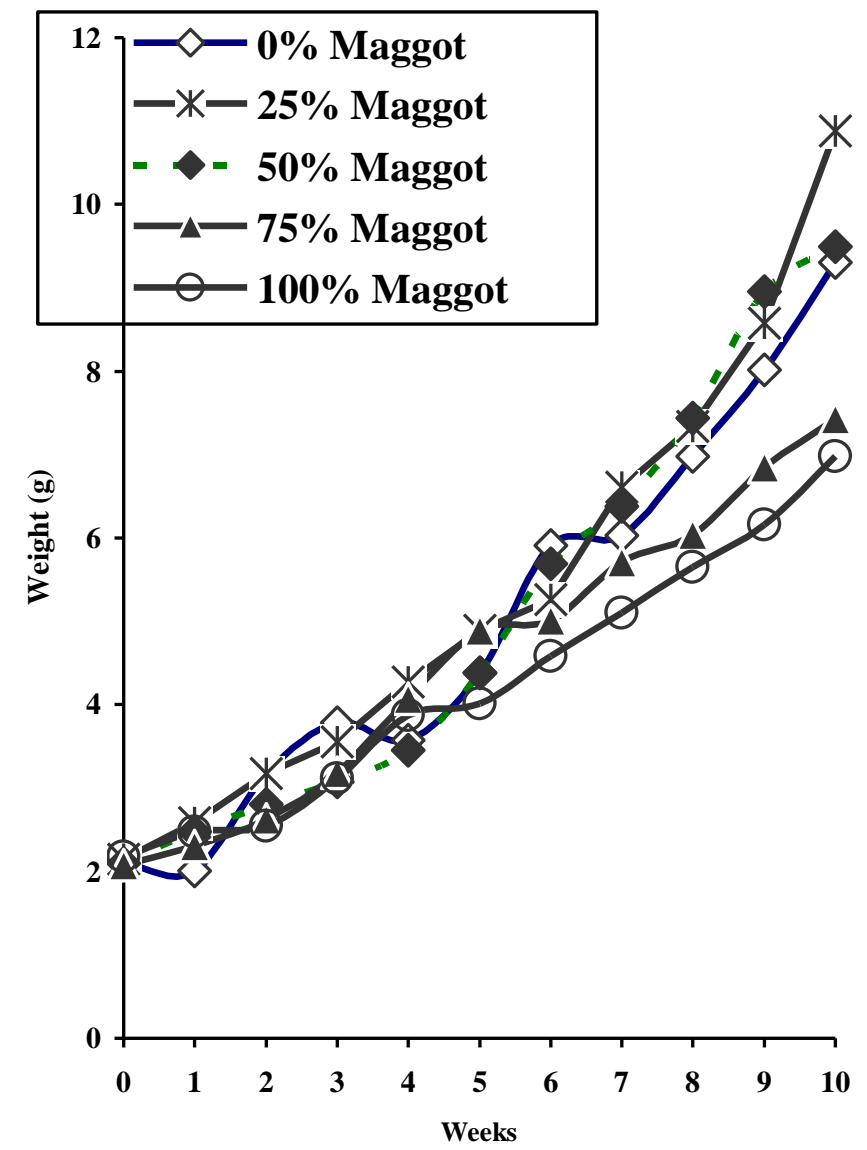

FIGURE 1: Growth pattern of Heterobrnachus longifilis fed Maggot meal supplemented diets for 70 days

Table 4. Correlation matrices $\mathbf{r}^{2}$ of Heterobranchus longifilis fingerlings fed maggot meal supplemented diets.

\begin{tabular}{|c|c|c|c|c|c|}
\hline & 0\% Maggot meal & $\begin{array}{l}\text { 25\% Maggot } \\
\text { meal }\end{array}$ & $\begin{array}{l}50 \% \text { Maggot } \\
\text { meal }\end{array}$ & $\begin{array}{l}75 \% \text { Maggot } \\
\text { meal }\end{array}$ & $\begin{array}{l}100 \% \text { Maggot } \\
\text { meal }\end{array}$ \\
\hline 0\% Maggot meal & 1 & & & & \\
\hline 25\% Maggot meal & 0.999877 & 1 & & & \\
\hline $50 \%$ Maggot meal & 0.999975 & 0.999955 & 1 & & \\
\hline $75 \%$ Maggot meal & 0.999848 & 0.999473 & 0.999734 & 1 & \\
\hline $100 \%$ Maggot meal & 0.9995 & 0.998907 & 0.9993 & 0.999892 & 1 \\
\hline
\end{tabular}


Table 5. Correlation matrices $r^{2}$ of the interrelationship between the growth, feed utilization, haematology and economic indices of Heterobranchus longifilis fingerlings fed maggot meal supplemented diets.

\begin{tabular}{|c|c|c|c|c|c|c|c|c|c|c|c|c|c|c|c|c|c|c|}
\hline & WG & $\mathrm{RGR}$ & $\mathrm{MGR}$ & $\mathrm{SGR}$ & IFI & $\mathrm{FCR}$ & $P R$ & PER & GEI & s & $\mathrm{K}$ & $H(0,6)$ & $\mathrm{Hb}$ & WBC & $\mathrm{CT}$ & PI & $\mathrm{I}_{0} \mathrm{C}$ & $\mathrm{BCR}$ \\
\hline wG & & & & & & & & & & & & & & & & & & \\
\hline RGR & 0.997392 & 1 & & & & & & & & & & & & & & & & \\
\hline MGR & 0.993919 & 0.999194 & 1 & & & & & & & & & & & & & & & \\
\hline$S G R$ & 0.991898 & 0.998389 & 0.999531 & 1 & & & & & & & & & & & & & & \\
\hline VFI & 0.333087 & 0.368321 & 0.392758 & 0.38042 & & & & & & & & & & & & & & \\
\hline FCR & -0.92063 & -0.91599 & -0.90857 & -0.91577 & 0.018939 & 1 & & & & & & & & & & & & \\
\hline PR & 0.988059 & 0.991512 & 0.990795 & 0.992879 & 0.276949 & -0.95432 & 1 & & & & & & & & & & & \\
\hline PER & 0.949497 & 0.942831 & 0.934654 & 0.939487 & 0.040768 & -0.99563 & 0.969664 & 1 & & & & & & & & & & \\
\hline GEI & 0.991501 & 0.991984 & 0.99162 & 0.987204 & 0.445468 & -0.86699 & 0.971357 & 0.902789 & 1 & & & & & & & & & \\
\hline s & 0.158389 & 0.157336 & 0.171845 & 0.152337 & 0.532307 & 0.064985 & 0.126886 & -0.03424 & 0.255994 & 1 & & & & & & & & \\
\hline $\mathrm{K}$ & 0.68532 & 0.71402 & 0.734007 & 0.738736 & 0.377912 & -0.66581 & 0.7534 & 0.651154 & 0.709631 & 0.516821 & 1 & & & & & & & \\
\hline $\mathrm{H}(0,0)$ & -0.1134 & -0.15998 & -0.18773 & -0.18099 & -0.94578 & -0.20431 & -0.0707 & 0.155358 & -0.21924 & -0.31226 & -0.18892 & 1 & & & & & & \\
\hline $\mathrm{Hb}$ & -0.17409 & -0.21867 & -0.24491 & -0.2377 & -0.95508 & -0.14947 & -0.12663 & 0.097037 & -0.27753 & -0.30036 & -0.20205 & 0.997387 & 1 & & & & & \\
\hline WBC & 0.536919 & 0.543364 & 0.555645 & 0.535066 & 0.876387 & -0.18572 & 0.457417 & 0.255823 & 0.63982 & 0.74981 & 0.486431 & -0.67696 & -0.70187 & 1 & & & & \\
\hline CT & -0.84575 & -0.8173 & -0.7988 & -0.80002 & 0.202803 & 0.93971 & -0.85498 & -0.94109 & -0.78205 & 0.017471 & -0.51157 & -0.43388 & -0.37699 & -0.13177 & 1 & & & \\
\hline PI & -0.68453 & -0.70698 & -0.72234 & -0.71054 & -0.91244 & 0.368067 & -0.62663 & -0.43115 & -0.76773 & -0.47052 & -0.54135 & 0.773236 & 0.808714 & -0.91632 & 0.208967 & 1 & & \\
\hline $\mathrm{Io}_{\mathrm{C}} \mathrm{C}$ & 0.349311 & 0.378431 & 0.399952 & 0.385209 & 0.995475 & 0.017305 & 0.280704 & 0.048633 & 0.46236 & 0.552536 & 0.344777 & -0.92406 & -0.93688 & 0.906139 & 0.174645 & -0.92161 & 1 & \\
\hline $\mathrm{BCR}$ & 0.987941 & 0.989841 & 0.987706 & 0.990163 & 0.247983 & -0.96268 & 0.998966 & 0.97774 & 0.966464 & 0.087585 & 0.72658 & -0.04612 & -0.10352 & 0.429186 & -0.86815 & -0.60575 & 0.252948 & 1 \\
\hline
\end{tabular}

Keys: WG (Weight gain), RGG (Relative growth rate), SGR (Specific growth rate), VFI(Voluntary Feed Intake), FCR (Feed Conversion rate), PR (Protein rating), PER (Protein efficiency rate), GEI (Gross Energy Intake), S(Survival), K (Condition factor), H(Haematocrit), Hb(Haemoglobin), WBC (White Blood Cell), CT (Clotting time), PI (Profit Incidence) IoC (Incidence of cost) and BCR (benefit Cost Ratio) 